\title{
“Krimnash": Is the Cold War Over?
}

\author{
Rumen Kanchev \\ Plovdiv University "Paisii Hilendarski”, Plovdiv, Bulgaria \\ Email: rumen.kanchev@gmail.com
}

How to cite this paper: Kanchev, R. (2016) "Krimnash": Is the Cold War Over? Open Access Library Journal, 3: e2766.

http://dx.doi.org/10.4236/oalib.1102766

Received: October 6, 2016

Accepted: October 28, 2016

Published: October 31, 2016

Copyright $\odot 2016$ by author and Open Access Library Inc.

This work is licensed under the Creative Commons Attribution International License (CC BY 4.0).

http://creativecommons.org/licenses/by/4.0/

(c) (i) Open Access

\begin{abstract}
This article analyses the situation since the annexation of Krim by current leadership in Kremlin. It presents some possible scenarios of further development of RussiaUkraine relations. The paper also analyses contemporary Russian foreign strategy towards the World of the Western Liberal Democracies.
\end{abstract}

\section{Subject Areas}

International Relations, Military Science

\section{Keywords}

Krim, Geopolitical Trends and Consequences, Russia, Eurasian Union, Ukraine, Scenarios

\section{Introduction}

"Essentially, 'Krimnash' and the practical tearing away of the Ukrainian Southeast turned into the 'loser's march'. This was the last parade of forces that had undergone a historical defeat in the fight against globalization. They lost in their clash with the open society and the mobilization of citizens, with Internet and with the European Union, with modern art and the financial markets, with 'soft force' and complex structures. The Crimean resentment... is the apologetic defense of weakness, a defense reaction of a departing reality, a historical dead-end."

Sergey Medvedev, The Ukraine Mania [1]

A year and a half after the events on Maidan Square (November 2013), the escalating conflict between Russia and Ukraine has still not reached its peak. Relations between Kiev and Moscow are now taking the form of military action between the armed forces of the two states. The agreements concluded at the Minsk 1 and Minsk 2 talks conducted in the Normandy format are not being fulfilled, and the toll of casualties among the civilian population is rising. With these developments, the crisis is acquiring the 
dimensions of a wide regional conflict, in which Europe and USA are participants. On several occasions, prominent Russian politicians have talked about a world war, recalling that their country possesses nuclear weapons.

Dr. R. Kanchev teaches IRT, International Conflict \& Crisis Management, Geopolitics, etc. in NBU (Sofia) as well as in Plovdiv University "Paisii Hilendarski" (Plovdiv). Among the books he published in the last years are: The Paradox of Russian Democracy (2007); Why Russia Does Not Pursue a Western-Style Democracy (2008); Strategic Stability. American Anti-Missile Defense, Russian Air-Space Defense, and Strategic Stability since the Cold War (2014), etc.

As we know, in March 2014, the Kremlin conducted a specially planned military operation of the so-called hybrid type in Crimea and, not without the consent of the predominantly Russian local population, annexed the Crimean Peninsula, making it part of the territorial, political and military structure of Russia ${ }^{1}$. This annexation of territory belonging to a sovereign European country by another country happens for the first time since the end of World War II. It must be emphasized that this is the most severe crisis in relations between Russia and the liberal democracies since the end of the Cold War, and also that it will seriously change the political and strategic parameters established on the global political stage after the Cold War. By March 2015, a year and a half after the beginning of the crisis, the international community has been unable to find an approach or formula by which to resolve it.

In this study, I will analyze the standpoint of Russia and that of Ukraine, which is supported by the Western democracies. How things came to this grave situation, what the causes of the crisis are, what factors are triggering the escalation, and other such questions, will not be the topic of this study. Instead, it will analyze two key aspects: first, the geopolitical consequences and trends that the crisis is producing in the relations between the Western democracies and Russia, and, second, the possible scenarios for the further development of these relations in a short-term and middle-term perspective. Also, I will attempt to demonstrate the possibility that the crisis may escalate in a way that may radically change the very geostrategic context of US and EU relations with Russia, generating profound and long-term problems on the world political stage.

\section{The Economic Strategy}

Neither the US and EU, nor Russia are aiming at military confrontation between each other in this conflict. The Cold War ended too recently and the two nuclear superstates are perfectly aware that their geostrategic rivalry must be pursued by means of "soft" and "intelligent" power [2]. Understandably, the chosen instrument of soft power was economic sanctions on Russia, and these are consistently being expanded. After the first 7 - 8 months of sanctions, Russia is quickly entering a severe economic crisis. The

${ }^{1}$ The international community has qualified the annexation of Crimea by Russia as an inad-missible act of aggression against a politically independent state with sovereign territory. It was condemned by the UN. At the session of the Organization, at which the US proposed a declaration condemning Russia's actions in Crimea, 99 states voted against the annexation of Crimea by the Russian Federation, 82 states abstained, and only 10 supported Russia's position, none of which are democracies. 
inflation rate of the country is approximately $11.5 \%$, the exchange rate of the Russian ruble to the US dollar by February 2015 was about 68:1. Investments in Russia during the time of the sanctions have decreased by about $45 \%$. Let us recall that the share of the gross domestic product (GDP) of Russia in relation to the world annual GDP in 2014 was about $2.9 \%$, which amounts to only $6 \%$ of the total annual GDP of the NATO countries.

The standpoint of the American and European political and scholarly community is shaped around two very important elements. The first of these may be defined as civilizational. It is related to one of the key strategies launched by Europe and supported by the US immediately after the end of the Cold War, namely, the expansion of the European Union. In the strictly civilizational aspect, EU expansion aims to restore Europe's civilizational identity, which was partially lost during the Cold War, by integrating those parts of Europe, for instance Eastern Europe, which have always belonged to the European civilizational area in terms of their history, culture, civilization and values. In this context, Europe, actively supported in this by the US, considers Ukraine to be part of the space of European culture and civilization. The predominant part of the Ukrainian population agrees with this. The early parliamentary elections held in Ukraine on 26 October 2014 as well as the early presidential election (May 2014) demonstrated this striving of the Ukrainian population for European identity. It could be interpreted as a striving to break away from Russia, from the Russian sphere of influence. Personally, I prefer to call this "a striving towards European civilizational, economic, political and cultural identity". No nation should be denied the right to be part of Europe as long as it identifies itself as European in its culture and civilization, in its desire and will to be part of Europe.

The second element is geopolitical and geostrategic. Its early herald was Prof. Zbigniew Brzezinski, one of the strategists of American Cold War policy. He stated and theoretically developed it for the first time in the start of President Clinton's second presidential term. In his book The Grand Chessboard: American Primacy and Its Geostrategic Imperatives (written in 1995-96 and published in 1997), and in hundreds of articles and interviews given for television in the US and Europe, Brzezinski states:

"Ukraine... is a geopolitical pivot because its very existence as an independent country helps to transform Russia. Without Ukraine, Russia ceases to be a Eurasian empire. Without Ukraine, Russia may continue to strive for imperial status but will turn into a primarily Asiatic imperial state, getting involved... in exhausting conflicts with the rising Central Asiatic countries, who would hardly reconcile themselves to the loss of their newly obtained independence and would be supported by friendly Islamic states to the south. China would also probably oppose any revival of Russian dominance over Central Asia...” ([3], p. 57).

In Eurasia, defined by Brzezinski as a "grand chessboard", Ukrainian-Russian relations are of exceptional geostrategic importance and are a factor that may open or close the horizon to American global dominance over the world. The issue can be expressed 
in the following maxim formulated by Brzezinski:

"If Moscow regains control over Ukraine, with its 52 million people and major resources as well as access to the Black Sea, Russia automatically again regains the wherewithal to become a powerful imperial state, spanning Europe and Asia"([3], p. 57).

Here, the famous American strategist is not saying anything new, as he is leaning on the views regarding Eurasia formulated more than a hundred years ago by the founder of European geopolitics, Sir Halford Mackinder. Studying the question of global dominance, Mackinder reached the conclusion that the Eurasian continent was of crucial importance in this regard. He defined world power with reference to three areas on the map, which he considered to be of exceptional strategic importance: "East Europe", "the Heartland", and "Eurasia" ("the World-Island"). The geopolitical correlation between them serves as the formula for world dominance. He summarized it thus:

"Who rules East Europe commands the Heartland;

Who rules the Heartland commands the World-Island;

Who rules the World-Island commands the World." ([4], p. 113)

Brzezinski is simply repeating the third element of the formula when he states: "Control over the entire Eurasian continent serves as a basis for global supremacy" ([3], p. 49). Global dominance, according to Brzezinski, is central to American strategy after the end of the Cold War.

I quoted these views of the American strategist in order to outline the theoretical platform that, despite their differences, has united American politicians and analysts of the neoconservative school, which was dominant in American foreign policy during the two presidential terms of George W. Bush (2000-2008). These views show, clearly enough, what lies at the core of American geopolitical interest in Ukrainian-Russian relations.

\section{The Kremlin and the Crisis}

As paradoxical as it might seem at first glance, Russian strategists and politicians repose on approximately the same geopolitical arguments. The Kremlin is perfectly aware that EU membership would impart to the Ukraine a different historical dynamism from that of the political, economic, and cultural development of Russia or of Central Asia. Leaving or abruptly distancing itself from Asia and getting closer to Europe is a basic political motivation underlying the developments in Ukraine since the so-called Orange Revolution in 2005. Respectively, Moscow's policy has certainly been to try to stop these plans of Kiev, and to preserve Ukraine for a possible geopolitical construction that the Kremlin conceives of as reintegration around Russia of the so-called post-Soviet space in the context of political realities in the early $21^{\text {st }}$ century.

On the other hand, the territorial integration of Ukraine in the Western structures would create for Moscow operative-strategic deficits in two zones: the zones covered by the Central-Asiatic (South Command) and the West European (West Command) regional military commands. However, there are at least two additional elements in the 
Kremlin's strategy. One is related to expansion of NATO after the end of the Cold War and the active policy of the North Atlantic Alliance and the EU in Central Asia. According to the Russian analysts, NATO expansion narrows down the geopolitical perimeter of Russian influence and restricts Moscow's possibilities for pursuing an active policy both in Europe and in the Middle East, situated next to the European continent.

As we know, during the Cold War the Soviet army had excellent operative-strategic possibilities for a rapid and successful land invasion of Central Europe. According to the analyses of most students of NATO-Warsaw Pact relations, at no stage of the Cold War did NATO have supremacy in this region over the Warsaw Pact armies with respect to conventional arms and military forces ([5], p. 104). This paradigm was valid only during the Cold War, but by force of habit, the Russian military never stopped seeing NATO enlargement as a threat to Russia, specifically, to the country's strategic interests and global ambitions. That is why Russian strategists easily interpreted the events of the Ukrainian Orange Revolution (2005) and Maidan as a preparation for NATO expansion. In fact, the NATO Summit in Bucharest in April 2008 adopted a Declaration, article 23 of which states: "NATO welcomes Ukraine's and Georgia's Euro-Atlantic aspirations for membership in NATO. We agreed today that these countries will become members of NATO" ([6], art. 23).

After World War II, as a result of the Yalta agreements between the US, the Soviet Union and Great Britain, Moscow acquired unlimited military, political, strategic and ideological control over Eastern Europe. This changed dramatically in 1989 with the breakdown of the Soviet Union and the dismantling of the Warsaw Pact. The enlargements of the EU and NATO, initiated in the second half of the 1990s, severely restricted Russia's potential for exerting influence in Europe. This situation impelled Russian foreign policy thinkers to elaborate the plans for establishing the Shanghai Cooperation Organization (SCO), which, in a geopolitical perspective, was meant to expand Russian influence in Central Asia and towards the Southeast. This strategically promising orientation of Russian foreign policy, however, gradually entered a phase of stagnation after 2002-2003 due to China's powerful economic breakthrough, which made it the second strongest world economy in 2012-2013. The economy of the People's Republic of China was growing at annual rates of $8 \%$ to $12 \%$ during a whole decade, and in parallel with this, Beijing steeply increased its defense expenditure. While in 2000 China's military budget was approximately 39.5 billion US dollars and Russia's was about 29 billion, in 2013 the Chinese leadership spent 171 billion dollars on defense and defense research, while Russia spent 84.8 billion. Thus, a second strategic direction for expanding Moscow's global influence was strongly restricted by China's economic breakthrough and its ambitions to become a global superpower. In the middle and long term, Beijing will endeavor to prevent any foreign power from establishing geostrategic, military, political, and economic dominance in Southeast Asia. This means that, to the great displeasure of today's political elite in the Kremlin, on the south and southeast, Russia is in fact facing a powerful economic and military rival that is no less ambitious than the EU and NATO are at Russia's west. The 400 billion dollar agreement signed in July 
2014 between Moscow and Beijing for the construction of a new pipeline supplying energy sources to China can hardly change the basic characteristics of their rivalry. The leading world research centers and experts assess that there is a high probability this agreement will prove unprofitable for Russia. It is obvious that, given the situation in the beginning of the $21^{\text {st }}$ century and the leading economic and political world trends, the Kremlin will find it hard to implement projects involving a special leadership role for Russia on the international stage. Russia continues to be a country whose basic foreign policy tool is production and trade with energy sources and, of course, the enlargement of its military, and particularly strategic nuclear missile, potential.

The facts and developments analyzed above have influenced the thinking of the Kremlin political elite and of Russian strategists, among whom there is a noticeable, though small, increase in the number of politicians and experts favoring a change of the foreign policy course and a turn back to Europe and the European Union.

Such are the geopolitical reality and strategic context that shape the Ukraine-Russia crisis today. It is not important for our analysis what specific diplomatic, literary, journalistic, propaganda, ideological, ethnic, international-legal, nationalist, anti or proRussian, anti or pro-Ukrainian style these realities are expressed in. What is more important, against the backdrop of the course of events unfolding after November 2013 and March 2014 (the annexation of Crimea), is what the consequences will be for the relations between Russia and the liberal democracies that support the democratization and Europeanization of Ukraine.

Indisputably, the crisis between Ukraine and Russia has a serious impact on stability in the region and is increasing the sensitivity of all the neighboring countries. The most important characteristic of this crisis is that it has the potential to radically redefine the global relations established after the end of the Cold War.

\section{Geopolitical Trends and Consequences}

In the short-term and middle-term perspective, the most important geopolitical trends and consequences of the crisis are the following:

1) The crisis has given additional impetus to the growing military rivalry between Russia on one hand and the US and NATO on the other.

2) The crisis has provoked intensified economic rivalry between Russia and the Western democracies. The sanctions imposed by the US and the EU on Russia are a new element of this rivalry.

3) The crisis has outlined the initial parameters of a confrontation of values (ideology) between Russia and the liberal democracies. Instead of the course towards rapprochement with Europe and the liberal democracies, pursued by President Boris Yeltsin after the end of the Cold War, today Russia is trying to build relations with Europe upon a certain philosophical conservatism that proposes the return to Russian traditional spiritual values, the revival of the concept of the great state as a basic foreign policy doctrine and views the Orthodox Church as a carrier of this traditionalism. The political expression of this course is the idea of building a "Eurasian Union", officially 
proposed by President Putin in 2011.

4) After the annexation of Crimea and the continuing attempts at destabilizing southeastern Ukraine, including the creation of two artificial formations called Donetsk People's Republic (DPR) and Luhansk People's Republic (LPR), nothing can now stop the accelerated preparation of a global anti-missile defense by the US, the perfecting of the elements of that system, and the search for a reciprocal response by Russia. This sets the beginning of a new stage in military-strategic relations in the world, a stage similar to the bipolar strategic containment during the Cold War. At that time, the main result of containment was the buildup of armament and military forces in the world nearly until the very end of the Cold War.

5) The crisis has provoked a sharp increase in the military budgets of the NATO countries The Wales Summit Declaration of the NATO member states, adopted in Wales (UK) on 5-6 September 2014, states that in the next 10 years the military budgets of all member states will reach $2 \%$ of their GDPs. It was also decided at the summit that no less than $30 \%$ of the countries' military budgets should be spent on rearmament, on upgrading the existing armament systems and on constructing new ones. Although in the last few years the military budget of the US was reduced from 710 to 640 - 620 billion US dollars, the budget will probably grow again in the coming years ${ }^{2}$.

6) The crisis has provided an additional motive for developing the economic alliance, strongly growing in recent years, between the US, the European Union, Japan, Canada, and South Korea.

7) The crisis has developed into an intense political and geostrategic challenge between the US and Russia. It has served as a very strong stimulus for the right, neoconservative wing of the Republican Party in America, which in 2000 launched the New American Century project, aimed at ensuring the world leadership of the US in the $21^{\text {st }}$ century. In November 2014, at the midterm elections for the Senate and the House of Representatives, the Republicans won a crushing majority in both chambers. This proportion between Republicans and Democrats will be preserved, and at the presidential election in 2016, the power of the neo-conservatives will almost certainly increase additionally with the election of a Republican as President of the US. The Republicans have always maintained a firmer course towards Russia. In the context of the tense relations between Washington and Moscow over the Ukraine, the majority of Americans expect that this course will lead to funding additional military programs, means of intelligence and control, anti-missile programs, etc. The other world powers will probably follow a reciprocal course, which means that the growth of military budgets of the US, China, Russia, EU, Japan, and other important states will continue in the middle-term and long-term perspective (see Table 1).

8) The crisis in Ukraine has had one more important geopolitical result. In the vague, disputed, strategically incomplete polycentricity of the modern world, this continuing crisis has introduced an element of bipolarity. A. Arbatov, from the Russian Academy

${ }^{2}$ At the hearings before the US Senate Committee on Armed Services in January-February 2015, its chairman, Senator McCain indicated that the military budget of the country would grow in the following years, reaching a little over 1 trillion dollars in 2020 . 
Table 1. Military budgets, 2015.

\begin{tabular}{cc}
\hline Country & Military budget in US \$ \\
\hline USA & 640 billion \\
China & 188 billion \\
Russia & 84.7 billion \\
Japan & 59 billion \\
Great Britain & 57 billion \\
\hline
\end{tabular}

Source: IISS, London 2015.

of Sciences, has designated it as "asymmetric polycentricism". The asymmetry is created by a new regrouping of economic and strategically important global players. An example of such asymmetry in the contemporary polycentric world is seen in the results of the vote taken by the UN in connection with the referendum in Crimea. Russia's position in support of Crimea's joining the Russian Federation (after the referendum) was backed by 10 states (Syria, Cuba, Venezuela, Armenia, North Korea, Ghana, etc.), none of which are democratic countries. The US stance against the annexation was supported by 99 states. None of the BRICS countries (apart from Russia) supported the annexation. (About $40 \%$ of the total $82 \mathrm{UN}$ member states abstained, preferring to maintain their relations with both Washington and Moscow.)

9) The general trend of the Kremlin's foreign policy course after the annexation of Crimea is towards intensifying the confrontation with the US and EU. One other tactical element of this course is becoming increasingly clear-the attempt to destabilize southeastern Ukraine (Dontesk and Luhansk). In other words, the Kremlin's policy contains the basic elements of escalation of tension in the middle-term perspective between Russia on one hand and US and EU on the other.

10) Despite the economic sanctions imposed on Russia by the EU and USA, the Western liberal democracies are hardly planning a long-term escalation of tension in their relations with the Kremlin. A possibility for compromise and reversal has been formulated, providing Moscow wills it. The Russian political leadership, however, has not accepted the parameters of the compromise proposed by the US.

This list may be continued; a more important question is what the possible solutions or variants are that might satisfy both Ukraine, supported by the US and EU, and Russia. What are the possible scenarios for the further development of the realities and geopolitical trends described above and what are the chances that relations will be regulated?

\section{Scenarios}

When studying complex social-political processes, situations and trends, the hardest part of analysis is predicting what is yet to happen. The usual procedure in such cases is to point out the closest possible variants (scenarios) for the development of events. However, the scenarios elaborated by analysts hardly ever materialize. There is a countless number of factors and of the oretically possible variants in social reality. That 
is why prognostic scenarios primarily represent attempts at outlining hypothetically possible situations linked to some most probable combination of currently operative factors. Reality can never be grasped beforehand in the version that will actually be realized. Of the hundreds of theoretically defined possibilities, only one will occur in reality. Hence, to list scenarios is part of the analysis of the phenomenon, event, process.

Based on the geopolitical factors and trends listed above, we will define three possible, and to some degree probable, scenarios for the development of the crisis. Our main goal, however, is to use the scenario tools in order to "describe" a hypothetically possible development of the Russia-Ukraine crisis in the context of the relations between the Kremlin and the Western liberal democracies. But the geostrategic focus of study will remain the same: the Ukraine-Russia crisis represents an attempt to redefine strategic relations a quarter of a century after the end of the Cold War.

Scenario 1: Intensification of the strategic rivalry between Russia and the liberal democracies. An attempt to change the world order (balance) at the start of the $21^{\text {st }}$ century.

If Moscow continues to take into consideration its assessment of the geopolitical role of Ukraine as being a key element for the restoration of Russian global influence, and continues to strive to restore its status of a world superpower, as the Soviet Union was during the Cold War, then the Kremlin's confrontation with the Western liberal democracies will continue to grow in the coming years. The US and the liberal democracies won the Cold War, expanded the zone of liberal freedom, encompassing within it the former Central and Eastern European satellite countries of the Soviet Union, and expanded the North Atlantic Alliance as the main defense guarantee for the sovereignty of the countries in the Euro-Atlantic community. It was in the context of this reality that the new post-Cold War world order was built. It is hardly probable that any serious and responsible Western politician would consent that Russia be given back the status of world superpower that the Soviet Union had during the Cold War. The ruling elite in Moscow, however, has the ambition to correct this world order. The latest, very clear proof of this is President Vladimir Putin's speech at the $11^{\text {th }}$ Annual Meeting of the Valdai Discussion Club, The World Order: New Rules or a Game with No Rules? (24 October 2014). There the Russian president defined the situation today as the beginning of a "change of the world order" ([7], p. 1) established after the Cold War. According to him:

"The world is full of contradictions today... Sadly, there is no guarantee and no certainty that the current system of global and regional security is able to protect us from upheavals. This system has become seriously weakened, fragmented and deformed. It is my conviction that we could not take this mechanism of checks and balances that we built over the last decades, sometimes with such effort and difficulty, and simply tear it apart without building anything in its place. Otherwise we would be left with no instruments other than brute force. What we needed to do was to carry out a rational reconstruction and adapt it the new realities in the system of international relations. But the United States, having declared itself the 
winner of the Cold War, saw no need for this. Instead of establishing a new balance of power, essential for maintaining order and stability, they took steps that threw the system into sharp and deep imbalance (my italics, R.K.). The so-called 'victors' in the Cold War had decided to pressure events and reshape the world to suit their own needs and interests" ([7], p. 2).

I quoted this long passage from President Putin's speech as it demonstrates what was indicated in the above analysis of the geopolitical trends, namely, that the Russian political elite is striving for a new balance of power on the world stage. The Kremlin is ever more insistently showing it is not content with the position and influence Russia has in the world after the end of the Cold War. In the narrow sense, this implies a revision of the global geostrategic framework that resulted from the end of the Cold War, the disintegration of the Soviet Union in 1990-1991, and the dismantlement of the Warsaw Pact.

What follows from the unfolding of such a strategy in the short term and long term perspective? Foremost, there will be an emphasis on increasing the military power of the country, isolation from the West, attempts at breaking down the unity of the West, an intensive search for approaches to the reintegration of the old strategic allies from Soviet times, the engagement of new allies, etc. Is there any proof of the presence of such elements in Russian policy? In the last 15 years, Russia sharply increased its military budget. From 16.5 billion dollars in the last year of Boris Yeltsin's presidency (1999), it grew to 84.7 billion in 2013. The military industrial complex of the country was restored, and today, new systems of arms are being created intensively, the main emphasis being on strategic offensive nuclear arms. Moscow also plans to sharply increase (several times over) the country's strategic atomic submarine fleet. Confrontation with the Western democracies is growing, and Russia is attempting to destabilize them wherever possible, by whatever means. And finally, in 2011, in a speech likewise full of anti-Western rhetoric, President Putin proposed the idea of creating the so-called Eurasian Union, the geopolitical goal of which is to integrate the republics, and even some of the former satellite countries of the Soviet Union, under the leadership of Russia in the context of the new geopolitical realities. This program is not a momentary response to the current situation but represents a long-term strategic project. The Russian president is not hiding the fact that the project has been conceived as an alternative to Western liberal democracy.

How will the USA and EU behave if this scenario is realized and continued in the middle term and long term? There are two possible options. The first of these we might call a breakdown of Western strategic and political unity, and even a distancing of Europe from the USA at a certain stage. This option is realistic not only in view of the Russian strategy described above but also because the integration of the Ukrainian economy will not be a quick or easy process. Today, Ukraine is not prepared for membership in EU or in NATO. Its accession to the Europe an Union will be a long and difficult process both for the Ukrainians and for the European economy; in any case, it will be very costly in economic and political terms. 
The development of international policy under this option will certainly deal a heavy blow to international relations. But would such a development be beneficial for Russia itself? It is almost impossible to give an affirmative answer to this question. Whatever the Russian political elite might believe, such a development in world politics would hardly create the balance in world politics that President Putin is thinking about in his speeches and actions in recent years. On the contrary, this trend would create new misbalances and asymmetries between the states and generate instability and even greater insecurity, including, or especially, for Russia.

For instance, in such a situation, could Russia become a world leader or considerably increase its influence in the world? Such a goal is almost illusory in terms of its practical feasibility. The GNP of the EU, for instance is about 19.1 trillion US dollars. The GNP of Russia is within the range of $2.08-2.1$ trillion US dollars. The annual GNP of China is about 9.1 trillion US dollars. How could a state with the financial-economic indicators of Russia become a world leader amidst economic giants like the EU, U.S., China? Even the boldest optimists regarding Russia's future could not conceive this happening. And nor can the Russian political elite and the leader in the Kremlin. Then what is the point of the confrontation between the developed West and Russia in the context of which their mutual mistrust will keep on growing?

The second option under this scenario can be designated as putting increasing pressure on Russia, including financial, economic, diplomatic, and international pressure, restricting the country's positions on the international markets, global economics, world policy. In other words, if the Kremlin focuses its attention on the idea of changing the world order that was established after the Cold War, then Europe and the US have a second option: maintaining their strategic unity and simultaneously following the policy of exerting pressure on Russia. In fact, after the events in Ukraine and the annexation of Crimea, no one-neither the UN, nor SCO, nor anyone else-can stop these two processes: the consolidation of the North Atlantic Alliance and Washington's endeavor to increase its superiority over the Kremlin and Washington in the sphere of high tech systems of defense and security, such as the well-known US Global Missile Defense; perfecting the elements of the Prompt Global Strike Doctrine, etc. These are systems that, as Russian experts themselves assess, Russia will not be able to build before 2025-2030. This option, like the first one, will hardly produce greater security and stability in the world.

In assessing the first scenario, we must point out that it has many similarities to the development of the world after the end of World War II. The end of that war set the beginning of an intense global geopolitical conflict that arose under the guise of an implacable ideological struggle between Capitalism and Communism. The end of the Cold War created hopes that the conflict had ended. This proved to be illusory, for in the last more than two decades a geopolitical regrouping occurred which started a new geopolitical conflict, of which we are now experiencing the initial phase. This conflict is no longer between Communism and Capitalism; now it is presented as a confrontation between the spiritual values of Russian traditionalism and conservatism on one hand 
and Western liberalism on the other. Why does this formulation of the conflict only mask the underlying issue? The true issue of the confrontation is geopolitical control over Eurasia, presented as rivalry for influence over the so-called post-Soviet space. Control over Central Asia will increase Moscow's chances of integrating the post-Soviet space. Dominance over Central Asia will increase the possibilities of the US and Japan to balance out the growing might of China. Like any geopolitical conflict, this one will continue for decades. If this is true, then clearly, in the coming years we may expect the Kremlin to continue its at tempts to destabilize Ukraine, and we may predict growing tension between the liberal democracies and Russia.

Scenario 2: Agreement on Ukraine. Renouncing the idea of a "Eurasian Union".

Despite the sharp deterioration of Russia's relations with Europe and the US in connection with the annexation of Crimea, and despite the Russian president's sharp, frankly confrontational tone with regard to American policy in his speech at the latest Valdai Discussion Club meeting (Sochi, 24 October 2014), Russia's return to European values and European integration continues to be an open strategic opportunity for the Kremlin. Let us recall that in 2007, likewise at an annual conference in Sochi, Putin said the following with respect to Russia's European choice:

"In its spirit and culture, our country is part of European civilization... Today, in building a sovereign and democratic state, we fully share those basic principles and values that build the worldview of the majority of Europeans (my italics-R. K.)... We view European integration as an objective process that represents a component of the emerging new world order... The development of many-sided ties with the EU is the general choice of Russia." ([8], p. 9)

Of course, after the annexation of Crimea, the return of Russia to Europe and the European road of development will be a slow and difficult process. Under this scenario, the Russian leadership will have to consent to an agreement with Ukraine, the EU and the USA, in which all sides will have to make compromises. The compromise that the Kremlin must make in order to restart relations with Europe is to acknowledge the right of the Ukrainian people to choose its own historical destiny. In other words, Russia must accept as a political reality that Ukraine wants to be a member of EU. Secondly, Russia should unconditionally recognize the sovereignty and territorial integrity of Ukraine, stop destabilizing the southeastern part of that country, and renounce its intention to fight for the autonomous status of Donetsk (with about 4 million voters) and Luhansk ( 1 million voters) in eastern Ukraine. Though these two regions have a predominantly Russian population, they are part of Ukrainian territory and Russia has no right to say how they should be governed. In fact, if the attempts to destabilize southeastern Ukraine continue, this will permanently drive Russia off the course-still a possible one-of a return to Europe. In addition, Moscow must expect, and accept as something normal, that Ukraine will become an EU member sometime in the period 2022-2025.

The second supporting element of an agreement between the Kremlin and the liberal democracies with regard to Ukraine is related to the security of Russia itself. In this re- 
spect, it would be fair for NATO to guarantee that Ukraine will not be accepted in the Alliance, so that NATO will not deploy elements of its military infrastructure in Ukraine.

The adoption of this second scenario by the leaders of Russia has the following advantages:

1) Russia would avoid its geopolitical, economic, etc., isolation, which can be expected to grow under the first scenario.

2) The Kremlin would continue to have the option of renewing dialogue with the US as regards the American global anti-missile defense and the further enlargement of NATO.

3) Russia would avoid the spiraling increase of confrontation with the NATO and EU countries, which are considerably more developed in industrial, technological, economic, financial, etc. aspects. Recognition of the realities of the early $21^{\text {st }}$ century requires pointing out that Russia is much less prepared for such a confrontation today than it was during the Cold War. In this perspective, the idea of the Russian political elite as to the creation of a "Eurasian Union" can be qualified as a dangerous geopolitical illusion. Russia does not possess the economic, financial or diplomatic resources to implement such a large-scale project. The gross national product of Russia amounts to one tenth that of NATO, and the country's share in the world economy is about $2.9 \%$. Experts from the well-know Peter Peterson Institute for International Economics, based in Washington, D.C., have made the categorical assessment that "Russia does not possess the economic potential to wage a war" ([9], p. 1).

First of all, such a project could be realized in not less than two or three decades, which would require a much more powerful economy than Russia can expect to have today and in the next decades.

Second, in order to realize such a large-scale project, the country requires a favorable military-strategic environment, such as would permit reducing defense costs to a minimum and rechanneling the free resources to spheres like the economy, education, and healthcare.

Third, the realization of the "Eurasian project" requires a lasting peace and mutually profitable cooperation with the developed liberal democracies, hence, a sharp reduction of confrontation with the centers of global economic, financial, military and technological power.

Fourth, the fulfillment of such a grand strategic project is not possible in the context of escalating military confrontation (in this case, with NATO) and a new cycle of rearmament.

Fifth, if the Kremlin is really aiming to increase Russian influence over the postSoviet area, it must minimize the international conflicts in which the country has become involved (such as the Ukrainian one now, or the one with Georgia in 2008).

Sixth, the more Russia tries to create division in Europe, the more obvious it will be for Europeans that they need the EU and should strengthen their collective defense with the US, as well as revitalize NATO. Russia will have time to make up for its high 
tech and industrial lag behind the world of the liberal democracies.

Russia will keep the perspective of being perceived and treated as part of Europe, and not as an Asiatic country.

This version, or a similar one, would be the beneficial scenario for Russia in view of the requirements of the strategic context and the geopolitical realities and trends after the Cold War and in the early $21^{\text {st }}$ century (Table 2 ).

Scenario 3: Eurasian union.

The development of Russia after 1991 has undergone two stages that are entirely different in their foreign policy orientation. The first stage was under the governance of President Boris Yeltsin and was characterized by a clearly pro-Western orientation to liberal democracy. President Yeltsin's policy was centered on the desire of the Russian political elite at that time for strategic partnership with the US. The politicians around Yeltsin believed that, since the Russians themselves were disappointed in the Communism that had been in construction for 70 years, and since the presidents Gorbachev and Yeltsin had personally taken part in dismantling the Soviet totalitarian system, it was normal that Russia should preserve its position from the Cold War period and continue to be a world superpower. Yeltsin and the people around him saw the future Russia as a European state in the European Union and, in their bolder dreams, as a member of NATO as well, in a long-term perspective. Coming to power in 2000, Vladimir Putin radically changed this political priority. Then began the second stage in the development of Russia after the Cold War; the basic elements of policy here were Putin's attempts to reintegrate the so-called post-Soviet space around Russia, either in some collective defense structure or in the form of economic cooperation (the SCO, including China), as well as the strategy of using energy sources as a means of exerting pressure on Europe. The high points of this process are two very important ideas personally expressed by President Putin.

Table 2. Annual BNP of world leading economics.

\begin{tabular}{cc}
\hline State & Annual GNP in US \$ \\
\hline EU & 19.1 trillion \\
USA & 16.7 \\
China & 9.1 \\
Japan & 4.9 \\
Germany & 3.7 \\
France & 2.8 \\
Great Britain & 2.7 \\
Brazil & 2.2 \\
Italy & 2.15 \\
Russia & 2.09 \\
Canada & 1.8 \\
\hline
\end{tabular}

Source: averaged data from UN, IMF, WB, CIA 2013-2015. 
The first idea involves the creation of the so-called customs union meant to facilitate economic ties in the post-Soviet space and to integrate the countries there along certain economic lines. This is how the "Ukraine" problem actually started-by the refusal of that country to take part in the customs union. Why Ukraine in particular? Because President Putin, like Z. Brzezinski, is convinced that, without Ukraine, Russia would lose its chances to once again become a world superpower.

Since the customs union never started functioning (for more than 4 years now, its membership consists only of the first three founding states plus Armenia, which joined in July 2014), Vladimir Putin decided to accelerate the process by proposing a new formula, a new model for integration of post-Soviet space around Russia. He presented this second idea of his in September 2013 at the international Valdai meeting in Sochi, and before that, in a theoretical program article published in October 2011, in which he writes about the "decline of the West", about the inability of liberal democracies to develop upwards under the conditions of the early $21^{\text {st }}$ century, about the aging of Europe and its continuously decreasing power, about "the crisis of the US" and their loss of moral authority after the wars in Afghanistan and Iraq. In his speech, Putin rejected the West's political system and its mentality and spiritual character. Putin stated that the Euro-Atlantic states had renounced the roots of Western civilization and, by their politics, had become a threat to human values, including Christian values. As an alternative to "the old woman Europe", as he styled it, Putin proposed the creation of a Eurasian Union that he qualified as the carrier of the new values for the $21^{\text {st }}$ century and as a "type of civilization". This new civilization, in his view, should serve as a counterweight or counterbalance to the world of liberal democracies. In the geostrategic aspect, the Eurasian Union should be built as an "independent center for global development". In this new "civilization-center" as Putin called it, the second most important element after Russia is Ukraine. As soon as they were publicized, these ideas of the Russian president became an important part of the foreign policy doctrine of Russia. It was because of the political contradiction between Ukraine and the "Eurasian Union" that the protests on Maidan Square began. Viewed in this perspective, those events and their developments until now seem to be not so much a matter of a geopolitical as a civilizational choice of the Ukrainians, a choice between the world of liberal democracies and the Kremlin's “Eurasian Union”.

The building of a new civilization through the reintegration of the post-Soviet space is an interesting and significant project in its conception. Certainly, this is Russia's most significant and most ambitious project in the time after the Cold War. It is not clear when, or whether at all, this project will be realized; it is too early to judge. Russia's orientation towards the Eurasian mega-project, however, will put Russia in a very difficult situation. First of all, the Eurasian Union project will hardly be accepted easily by the neighboring countries to the south-east. A powerful global player is located in that direction-China. As mentioned above, China is the second most powerful economy in the world and has set itself the priority goal of becoming "world power No. 1" in the following three decades. That was the decision and the program for China's develop- 
ment until 2050, adopted at the latest congress of the Chinese Communist Party. If the Chinese pursue this program, a powerful Eurasian Union built by the Kremlin will be perceived as a serious rival on China's path to global leadership. Sharp rivalry would automatically appear between Putin's Eurasian Union and China's ambitions for achieving world dominance in the following decades.

On the other hand, President Putin's severe criticism of the EU and USA, and his defining the "Eurasian Union" as an alternative to the liberal democracies, places Russia in a very hard position with regard to the highly industrialized world of the liberal democracies, which has an enormous advantage in the sphere of high technologies and has made powerful breakthroughs in almost all the fundamental directions of modern science. In fact, in undertaking the formation of the so-called Eurasian Union, the Kremlin is confronted with two powerful economic, military, strategic and political centers of power:

1) China, which is the world's second most powerful economy and harbors ambitions for world leadership in the near future, and

2) the powerful economic alliance between the USA-European Union-Japan-CanadaSouth Korea, which is intensively consolidating, especially after the annexation of Crimea, and which has behind it the only important military union today, NATO.

Assessed in this context, the "Eurasian Union" scenario implies that Russia will be involved in a very hard struggle for global influence, while lacking, at present, any significant strategic, economic or military allies. This would be a battle against two economic giants: China, with its annual GNP of about 9.1 trillion US dollars, and the alliance between the US, EU, Japan, etc., with a total annual GNP of over 40 trillion US dollars. We recall that Russia's annual GNP is about 1.4 - 1.5 trillion US dollars. While Russia's share of the world economy is about $2.9 \%$, that of the EU is around $24 \%-25 \%$, of China is $13 \%$, etc. Russia's military budget for 2013 was more than 15 times less than the combined military budget of EU, USA and Japan. Will Russia be able to balance these strategic, economic and military characteristics if it enters a new spiral of economic, military-strategic and political confrontation?

Scenario 4: George Kennan, offensive realism and Vladimir Putin.

George Kennan's famous LongTelegram, sent in February 1946 from the US Embassy in Moscow to the State Department established the parameters in the framework of which American political analysts built their policy conceptions regarding the Soviet bloc during almost the entire Cold War period. By force of habit, after the fall of Communism (1989-1990) this paradigm continued to be used as the most influential key to understanding Russia, which had already become a capitalist state. For strategists of the rank of Irving and William Kristol, Donald Rumsfeld, Dick Cheney, Zbigniew Brzezinski, Strobe Talbott, Brent Scowcroft, Madeleine Albright, James A. Baker III, the authors of the "New American Century" project, the Cold War has never ended, since its main strategic goal-reducing Russia's influence to that of a regional power in Asia, has not been fulfilled. All of these strategists, as well as the even more extreme ideologists of the Republican party, such as John McCain, Paul Wolfowitz, Francis Fukuyama, 
and Richard Haas, are convinced that the events in Crimea and the continuing destabilization of Eastern Ukraine (Donetsk, Luhansk, etc.) are the surest proof of their view. If this line of American foreign policy becomes predominant after the next presidential election in 2016, the pressure on Russia will grow to an extreme. A sign of this is the planned military budget of the US, which is expected to reach over 1 trillion US dollars by 2020 .

In 2007, I published a monograph entitled The Paradox of Russian Democracy. As is customary in such cases, I invited friends and colleagues to the presentation of the book. In the course of the discussion on the book and on the topic of the study, I was very impressed by the assessment of a young diplomat from the French embassy in Sofia. He had read the book carefully and wanted to talk to me. In the course of our conversation, I understood that he was impressed by precisely that part of the analysis that I too considered central to the book. When I asked him what he found most interesting in the book, he abandoned diplomatic caution and said to me straightforwardly: "I was most strongly impressed by the part of your analysis in which you point out that Russia is strongly pressured by the West, so that the country's ability to make an honorable response is strongly reduced. Hence follows the very logical conclusion drawn in the book, that when 'cornered', Russia is prepared to do anything to restore its prestige as a world power, which it lost after the Cold War..." The French diplomat had understood something very important that I had tried to explain-as far as possible in a monograph-namely, that Western pressure on Russia has a limit, it cannot be without bounds.

In fact, this is where the most important part begins in the assessment of the Ukraine-Russia crisis. I am referring to the strategic capacity of the political decisionmaking elite in the Kremlin, to the strategic context created after the annexation of Crimea and the growing pressure brought to bear on Putin. If the situation continues and pressure grows stronger in the following years, there are three basic strategic resources upon which the Kremlin will be forced to build its balance with respect to the economic and nuclear missile power of the US and NATO. In a possible prolonged confrontation with the world of the Western democracies, Russia will rely on: 1) its strategic special-purpose nuclear forces (first and second-strike forces); 2) its economy, built upon an almost unlimited supply of energy sources, and 3) its enormous territory. The well-known political analyst of the realist school, John Mearsheimer (University of Chicago), is right that the Russian president, unlike his American counterpart, is acting like a realist in the crisis [10]. In the realist perspective, the annexation of Crimea, which is entirely incompatible with the principles of international law and the UN Charter, is a purely strategic move aimed at restoring the strategic symmetry that was impaired after NATO and the EU extended their enlargement as far as the boundaries of Russia, which left the Russian Federation in a highly vulnerable position in military terms. At the same time, if in his next moves the Russian president continues to act like a realist and follows the principles of offensive realism, this would mean following the strategy of prolonged destabilization not only of the Donetsk and Luhansk region but of 
Ukraine as a whole. If Putin continues to perceive the three enlargements of NATO (1999, 2004 и 2009) as acts of misbalancing of the strategic relations with US and NATO to the detriment of Russia, then, as an offensive realist, he would seek to restore that balance. But since Russia is technologically not equipped to build its own antimissile defense of the American type, nor to establish a high tech aerospace system for intelligence and early warning against nuclear missile attack, then the "containment" priority in this context would in fact be to increase the capacity and effectiveness of the means for first and second nuclear strike as well as the announced doctrine of preventive nuclear strike. That was done in new Military doctrine of Russian federation. If, however, we carefully read the texts that present the new Russian war doctrine, we will see that what they define as a "preventive nuclear strike" is essentially a first nuclear strike, since the circumstances in which Russia is obliged to defend its national security and make a preventive nuclear strike are defined all too broadly. Hence, in the context of increasing confrontation with the West, following their "containment" doctrine, the Russians will foremost develop their nuclear first-strike capacity. Under conditions of an anti-missile system that is in a weak or "critical" state, this is the only possible option for the Kremlin and is also justified from a political point of view. Evidently, this standpoint is perceived by the Russian political and military elite around Putin as being symmetrical with the pressure exercised by the West to draw Ukraine out of the Kremlin's zone of influence and eventually accept it into NATO and the EU.

The basic theoretical principle of the realist school is balance of power (rivalry). Realists view the global political stage as characterized by "anarchy". This anarchy is systematically generated in the world, and the only "instance" capable of containing (balancing) it is the power of each state.

Analyzed from a structural realistic perspective, the pressure put on Russia will generate a strategy of response based on the tendencies and realities indicated above. If this is so, the Kremlin can be expected in the coming years to sharply increase its military strategic potential and to restructure the Russian economy in favor of the military industrial complex. The results of the other two geostrategic realities will be integrated into a policy subordinated to this priority. In assessing the possible conduct of the Moscow political elite, we should take into consideration that the stronger the pressure exercised by the US and the Western democracies on Russia, the more insistently will the military and political circle around President Putin seek a symmetrical response to that pressure. Given the impossibility to base this response on Russia's relatively weak economy, its corrupt business elite isolated from the West, and its gross national product obtained mainly from production, transport and trade with energy sources, the focus will be on the country's military-industrial complex, armed forces and the development of an offensive nuclear ballistic missile potential. In the middle-term perspective, this strategy will generate certain negative consequences for the political development of the EU, and in the long term, it will lead to conflict between Russia on the one side and Europe and America on the other.

On September 11, $2001 \mathrm{Al}$ Qaeda made three terrorist attacks on symbolically im- 
portant sites in New York and Washington. Moscow's response was indicative and entirely in the framework of the Russian political elite's understanding that partnership with the US is of strategic importance. The Russian president immediately expressed his full support for the US administration and his wish for equal partnership in the fight against the impending new threat facing the world-international terrorism. At President Putin's initiative, Russia provided intelligence information on the terrorist bases of Al Qaeda in Afghanistan, where the Soviet army had fought for eleven years, and gave concrete logistic support for their localization and neutralization. Russia was prepared to resume a course of rapprochement with the US, but under certain conditions. The price of this "deal" was very precisely analyzed by Dmitriy Trenin:

"In 2002, it was said that Russia accepted American global leadership without undermining American positions; moreover, Russia was prepared to be the chief ally of the US, if in return it was given freedom of control over the post-Soviet space and the processes going on in Russia. At the end of 2002, Putin... began to realize the fact that he could not support such a position of collaboration with the USA, since, from the viewpoint of the political elite surrounding him, it was not producing real results".

This was essentially an attempt to redefine the zones of strategic control between Russia and the USA. It proved unsuccessful, however. The reason for its failure was not only America's desire to expand its presence in Central Asia and in the post-Soviet space. The wars that Americans had started in Afghanistan (2001-2013), Iraq (20032012), and the sharp rise in oil prices after 2004 provided Russia with the serious chance to get out of its state of economic collapse and to gradually abandon the idea of strategic partnership with the US. What followed was the sharp attack against US world leadership made by the Russian president in his speech at the annual Munich Security Conference (2007), his idea of a "Eurasian Union" (2011), and the annexation of Crimea (2014). Certain theoreticians from the school of neoliberal foreign policy consensus have tried to present this period as a time of "ups and downs" in Russian-American relations. I do not agree with this description. If we carefully retrace Russian and American foreign policy in the last ten or twelve years, we will easily find that there has been a gradual escalation of confrontation in the relations between the two countries. For more than 15 years, the Kremlin and Washington have been irreconcilably opposed on the most important strategic issues: NATO enlargement, the US constructing a high tech anti-missile defense system and stationing it in Europe, the enlargement of the EU, etc.

Taking into consideration all the facts and tendencies analyzed above, we will easily reach the conclusion that the Western democracies and the US must be prepared for a new as well as long strategic rivalry with Russia. For the Russians, this rivalry has already begun, and the Russian strategy has already been defined in terms of its key parameters and elements. The western democracies need to elaborate a new containment strategy that takes into account the strategic context following the annexation of Crimea and the forthcoming destabilization of Eastern Ukraine and, possibly, of all Ukraine, as well as the clear statements made by the Russian president regarding Rus- 
sia's desire to return to the world political stage as a strategic player on an equal footing with the US.

\section{Coda}

Despite their complexity and contradictions, the events in Ukraine have opened an important perspective for the Kremlin: the Russian governing elite can reconsider its foreign policy course and once again turn to Europe. Russia must develop as part of Europe, not as part of Asia. For this purpose, the Kremlin needs a significant international partner who, under a favorable development of relations, will be capable of facilitating dialogue between Russia and Europe. Only the US can be such a partner. Renewing dialogue between the US and Russia and the warming of relations between Washington and Moscow might reassure the Russians with regard to the countries to the Southeast and East by balancing in the long-term perspective the leadership ambitions of China, a country with a population of 1.3 billion people, which will sooner or later become a serious problem for the Kremlin. On the other hand, restarting Russian-American dialogue will preserve Russia's possibilities for trade, cooperation and business activities with the liberal democracies and for gaining access to Western technologies.

Does the liberal democratic world need Russia? This is a rhetorical question, for no important global problem can be resolved today without the active and constructive contribution of a democratic, non-authoritarian, cooperative and developing Russia. In fact, what underlies the oftentimes excessive and markedly aggressive rhetoric against the US and the world of the liberal democracies, and the impossible to realize idea of a "Eurasian Union", is precisely the desire of the Kremlin to be treated as a key player on the global stage in the $21^{\text {st }}$ century. Today, as well as, in the coming decades the Kremlin does not have the capacity to maintain successful global rivalry with the US, EU and Japan. However, Russia does have the necessary cultural, economic, military, historical characteristics for successful dialogue and cooperation with Europe, China and the US in all important spheres of multilateral, peaceful and long-term partnership. After "Krimnash", in the coming decades this partnership cannot be strategic, just as it could not be immediately after the end of the Cold War, but Russia would lose far more than it would gain from a new and prolonged confrontation with the world of the liberal democracies.

After the end of the Cold War, Russian policy is still inconsistent, without clearly fixed long-term and systematically pursued foreign policy priorities, without a realistically planned strategic horizon for its goals. This confusion is evident in relations both with the Western democracies and with China, in whom the Kremlin is seeking, though somehow haphazardly, the strategic friend with whom Russia can unite against the US and the EU; this search is doomed to fail. If we consider the last 4 centuries of RussianChinese relations, we will find only occasional and negligibly short periods in which the two countries have been allies. The great French historian of the Annales school, Fernand Braudel, in his classic work Grammar of Civilizations, has pointed out regarding 
this great civilization: "China has always considered itself a global power and a great civilization; it has always been convinced of its superiority over the rest of the Universe, in the superiority of its civilization, outside of which, in its own eyes, there is only barbarity" ([11], p. 252). The relations of Russia with China are as critically important for Russia's future as are its relations with Europe and the US. Building a close strategic and military partnership with Beijing would be very difficult, probably impossible, for the Kremlin. Already in the first decade after the end of the Cold War, the Chinese leaders sharply criticized Russia for her conduct with respect to America and Europe, and especially President Yeltsin's striving for strategic partnership with the US. It is obvious President Putin has read these pages of his country's history after 1990 and has probably understood why China has always followed a course of keeping a certain distance from the EU and the US. The main point in the Russian president's understanding is that he must behave like a realist on the international stage, meaning that he should situate Russia on that stage in terms of power. This means that we are facing a new stage of "deterrence", the principles of which were first formulated by George Kennan under different political, military and geostrategic circumstances.

The choice between Asia and Europe, between the East and the West, is not a choice that only the present-day Russian leader is making. It has been a choice perpetually faced by Russia during the last three centuries. Perhaps that is why it is so difficult for the Kremlin to devise a strategy for the $21^{\text {st }}$ century. The famous Russian philosopher Nikolai Berdyaev has wonderfully illustrated this state of confusion and paradox.

"The Russian people, he wrote, in their spiritual make-up are an Eastern people. Russia is the Christian East, which in the course of two centuries has been under the strong influence of the West and whose cultured classes assimilated every Western idea. The fate of the Russian people has been an unhappy one and full of suffering, it has developed at a catastrophic tempo, through interruptions and change of the type of civilization. In spite of the opinion of Slavophils, there is no organic unity in Russian history" ([12], pp. 7-8).

\section{Conclusion}

Probably due to these particularities of both the Russian people and the political elites that have governed Russia in the last centuries, the relations of this territorially largest country in the world are equally ambivalent both towards the East and towards the West. This ambivalence is constantly generating the paradox of Russian historical and geopolitical destiny, which today, in the beginning of the $21^{\text {st }}$ century, the Russian political elite is once again trying to resolve. As in all previous attempts, Russia is again trying to be different, and not part of Western civilization.

\section{References}

[1] Medvedev, S. (2014) The Ukraine Mania. http://www.strana-oz.ru/2014/6/russkiy-resentiment

[2] Nye, J. (2011) The Future of Power. Public Affairs, Perseus Books Group. 
[3] Brzezinski, Z. (1997) The Grand Chessboard. Basic Books, Harper Collins Publishers, Inc.

[4] Mackinder, H. (1944) Democratic Ideals and Reality. 5th Edition, Pelican Books, London.

[5] Lieber, K. and Press, D. (2013) The Next Korean War.

[6] NATO (2008) Bucharest Summit Declaration. Official Text, April of 3.

[7] Putin, V. (2013) Session of the International Valdai Discussion Club. World Order: New Rules or a Game Without Rules. The Quotations Are from the Internet Version of V. Putin's Speech, Published on the Official Page of the Kremlin. http://www.kremlin.ru/news/46860

[8] Arbatov, A. (2014) The Breakdown of the World Order. In Which Direction Will Russia Turn? Russia in Global Politics, 3, 9.

[9] Aslund, A. (2014) Russia Is in No Economic Shape to Fight a War. The Moscow Times, April 22, 2-3.

http://www.piie.com/publications/opeds/print.cfm?ResearchId=2600\&doc=pub

[10] Mearsheimer, J. (2014) Why the Ukraine Crisis Is the West's Fault. Foreign Affairs, September/October 2014, 77-90.

[11] Braudel, F. (1993) Grammaire des Civilisations. Flammarion, Paris.

[12] Berdyaev, N. (1960) The Origins of Russian Communism. University of Michigan Press, Michigan.

Submit or recommend next manuscript to OALib Journal and we will provide best service for you:

- Publication frequency: Monthly

- 9 subject areas of science, technology and medicine

- Fair and rigorous peer-review system

- Fast publication process

- Article promotion in various social networking sites (LinkedIn, Facebook, Twitter, etc.)

- Maximum dissemination of your research work

Submit Your Paper Online: Click Here to Submit

Or Contact service@oalib.com 